\title{
ARCHEOLOGICKÝ VÝSKUM KOSTOLA EVANJELICKEJ CIRKVI A. V. V ŠTÍTNIKU (OKRES ROŽŇAVA)
}

\author{
PETER TAJKOV
}

\begin{abstract}
Abstrakt: Príspevok predkladá výsledky výskumu evanjelického kostola v Štítniku v rokoch 2011-2013. Dopĺn̆a poznatky o jeho architektonickej histórii a prináša pôdorys jeho doteraz najstaršej známej stavebnej etapy. Výskum bol súčastou prípravnej dokumentácie kjeho plánovanej komplexnej obnove.
\end{abstract}

Kl'účové slová: kostol - gotika - vrcholný stredovek.

\section{Archaeological research into a Protestant church in Štítnik (Rožňava district)}

Abstract: This contribution presents the results of research into a Protestant church in Stitnik carried out in 2011-2013. It brings new information about its building history and the ground plan of the church in its earliest known phase. The research was part of preparatory documentation for the planned complete renovation of the church.

Key words: church - Gothic - high Middle Ages.

Štítnik sa nachádza v južnej časti Slovenského rudohoria, pod západnými úbočiami Plešiveckej planiny, v údolí potoka Štítnik. Pôvodne stredoveké hutnícke mestečko má dnes, okrem podlhovastého námestia a niekol'kých roztratených kúrií, dedinský ráz. Mesto nemalo hradby a jeho majitel’om slúžil na obranu vodný hrad. Sídlu však dominuje majestátna gotická stavba dnešného evanjelického kostola (obr. 1), ktorý si dodnes zachoval svoj stredoveký charakter. Najnovší stav historiografického bádania o samotnom sídle podáva M. Skalská (Skalská 2009, 57-58, 64, 146-160; tam odkazy na staršiu lit. a pramene). Štítnik pôvodne patril k obciam král’ovských služobníkov venujúcich sa kovaniu železa a v 12. storočí patril ku královskému prédiu Turňa. Skalská napriek absencii priamych písomných prameňov presvedčivo dokladá, že to bol Belo III. (1172-1196), kto vyňal rozsiahle územie západnej časti svojho turnianskeho panstva a daroval ho bánovi Dominikovi z preduhorského slovanského rodu Miškovcov (Skalská 2009, 58; Steinhübel 2016, 343-344). S priamou zmienkou o Štítniku sa stretávame až v donačnej metácii Bela IV. z roku 1243, ktorý toto územie krátko po ničivom tatárskom vpáde daroval synom Mateja z rodu Ákošovcov - Detrikovi a Filipovi. V roku 1320 pripadol Štítnik vetve Ákošovcov, ktorí sa odvtedy nazývali pánmi zo Štítnika (Csetneki) a v 15. storočí si tu postavili aj spomínaný vodný hrad. Štítnická farnost's Kostolom Panny Márie (ecclesie Sancte Marie de Chitnik)

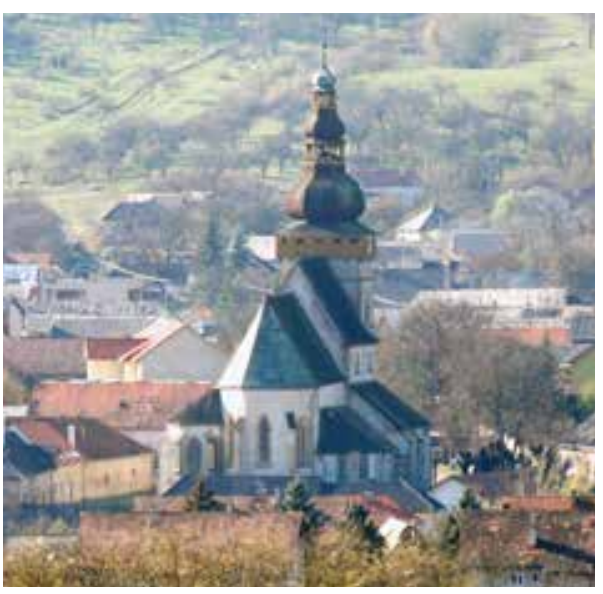

Obr. 1. Evanjelický kostol v Štítniku. Foto P. Tajkov. Fig. 1. Protestant church in Štítnik. Photo P. Tajkov. sa prvýkrát spomína až v súpise pápežských desiatkov z roku 1332 (MVS I, 41).

Doterajšie poznatky o kostole naposledy zhrnula B. Pomfyová (Pomfyová 2004, 643). Vo všeobecnosti sa predpokladalo, že dnešnej bazilike predchádzal bežný vidiecky kostol. Príznačným bol predpoklad M. Tognera publikovaný v práci z roku 1989 (Togner 1989, 57, 186), že v Štítniku stál už v 13. storočí kostol s rovným uzáverom presbytéria, ktorý bol zaklenutý dvoma pol'ami rebrovej klenby a s pozdížnou, zrejme plochostropou lod'ou. Jeho relikty videl v severnej sakristii dnešnej trojlod'ovej baziliky. B. Pomfyová uvádza, že pravdepodobne niekedy $\mathrm{v}$ druhej štvrtine 14. storočia sa Csetnekiovci púšt’ajú do prvej prestavby kostola. Domnieva sa, že už vtedy bola zrejme vymedzená základná dispozícia 


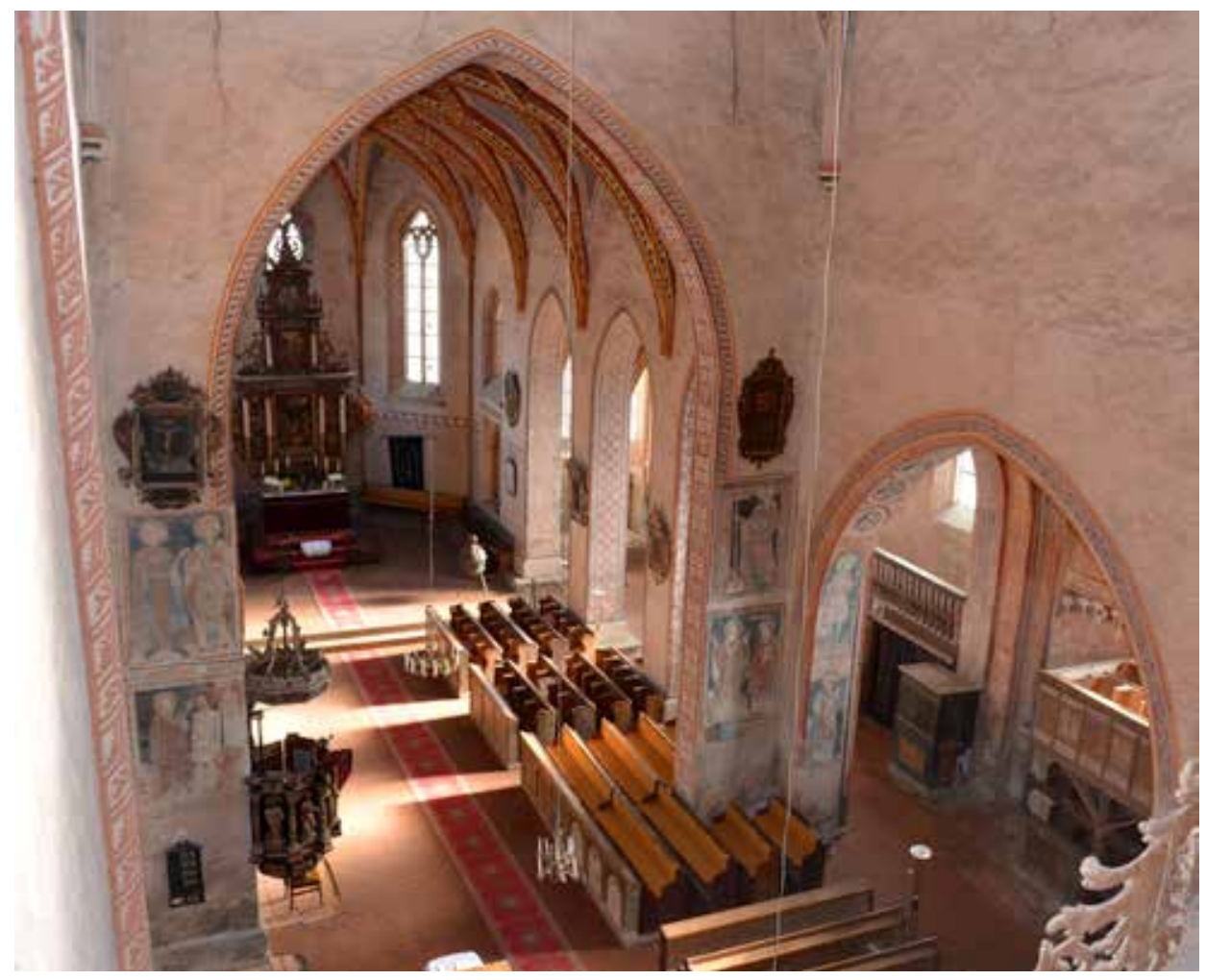

Obr. 2. Interiér evanjelického kostola v Štítniku. Foto P. Tajkov.

Fig. 2. Interior of the Protestant church in Štítnik. Photo P. Tajkov.

krátkeho bazilikálneho trojlodia, rozprestierajúca sa na híbku dvoch klenbových polí a hlbokého polygonálneho presbytéria. Rovnako podl'a nej snád' už pred polovicou 15. storočia vznikol zámer rozšírit' východnú čast' kostola o bočné chóry. Z plánovanej prestavby bol však realizovaný len južný, zaklenutý parléřovskou klenbou, severný ostal nedokončený. K. Kahoun spájal čast' týchto stavebných úprav s rokom 1446 (Kahoun 1970, 66). S istotou možno podla Pomfyovej datovat' len klenbu vo svätyni, a to do roku 1460. S neskorogotickou prestavbou tak súvisia aj dvoj- a trojdielne okná kostola a začiatok výstavby západnej predstavanej veže.

Mimoriadne dôležitú umelecko-historickú kapitolu dejín kostola tvorí jeho bohatá fresková výzdoba, objavená najmä počas obnovy začiatkom minulého storočia. Pochádza z viacerých etáp od 14. po 16. storočie a pomerne podrobne sa jej venovalo viacero odborníkov (napr. Dvořáková-Krása-Stejskal 1978; Plekanec-Haviar 2010, 14-15). Celý interiér baziliky s gotickými a renesančnými epitafmi, s hodnotným dreveným mobiliárom (napr. neskorogotické stallum rodiny majitel'ov či renesančné stallum cechu mečiarov), liatinovou krstitel'nicou z roku 1454, s mohutným barokovým organom z roku 1723, ale i vojenskými trofejami z bojov s Turkami tvorí vzácny a predovšetkým autentický obraz o vtedajšom bohatstve a význame tohto mestečka (obr. 2).

Archeologický výskum sme realizovali v rokoch 2011 až 2013. Okrem pomerne špecifických ciel’ov v roku 2011 (ošetrenie amatérskeho výkopu v sakristii a overenie funkčnosti modernej drenáže v exteriéri) bol vyvolaný predovšetkým potrebou vypracovania projektovej dokumentácie k obnove kostola. Túto dokumentáciu spracovávali autori architektonicko-historického 
výskumu (Klingová et al. 2012), ktorí iniciovali aj vykonanie archeologického výskumu. Tomu zodpovedalo aj umiestnenie archeologických sond v roku 2012, ktoré mali okrem dokumentácie vertikálnej stratigrafie terénu v miestach styku podlahy a mal'ovaných omietok osvetlit' najmä otázky týkajúce sa stavebného vývoja dnešného kostola. Posledná etapa výskumu kostola v roku 2013 predstavovala snahu spresnit', resp. potvrdit' získané poznatky o jeho najstaršej známej pôdorysnej dispozícii. Archeologický výskum bol determinovaný minimálnou dotačnou podporou, ktorá sa sústredila predovšetkým na architektonicko-historický výskum. V exteriéri bol výskum znemožnený mohutnou betónovou konštrukciou, slúžiacou k odvodneniu základov kostola. Táto konštrukcia z 80-tych rokov minulého storočia je však do značnej miery nefunkčná.

\section{Výsledky výskumu}

Preskúmaných bolo jedenást' sond v priestore dnešného trojlodia, chóru a sakristie kostola a jedna sonda $\mathrm{v}$ exteriéri objektu, $\mathrm{v}$ rámci ktorých sme identifikovali bezmála 100 rôznych stratigrafických jednotiek (vrstiev, konštrukcií, výkopov a pod.). Už z tohto počtu je zrejmé, že stavebná aktivita a tiež intenzita pochovávania v kostole boli pomerne výrazné. Na základe hnutel'ných archeologických nálezov nebolo možné datovat' všetky stratigrafické jednotky. Mnohé tak možno datovat' a interpretovat' len na základe vzájomných vzt’ahov a vzt’ahov k stojacej architektúre, ktorá už môže byt' predmetom morfologickej štýlovej analýzy. S tým súvisia predovšetkým úpravy podláh kostola, $v$ rámci ktorých sme zdokumentovali ich osem rôznych úrovní vrátane dnešnej, pochádzajúcej z obdobia poslednej komplexnej obnovy z roku 1909. Táto podlaha v podobe vlhkost' udržujúceho, pomerne hrubého betónového lôžka s keramickým prefabrikátom je z nášho pohladu, okrem iného, do vel'kej miery zodpovedná za dnešný kritický stav freskovej výzdoby. Výskumom boli odhalené aj niektoré časti stredovekého tvaroslovia

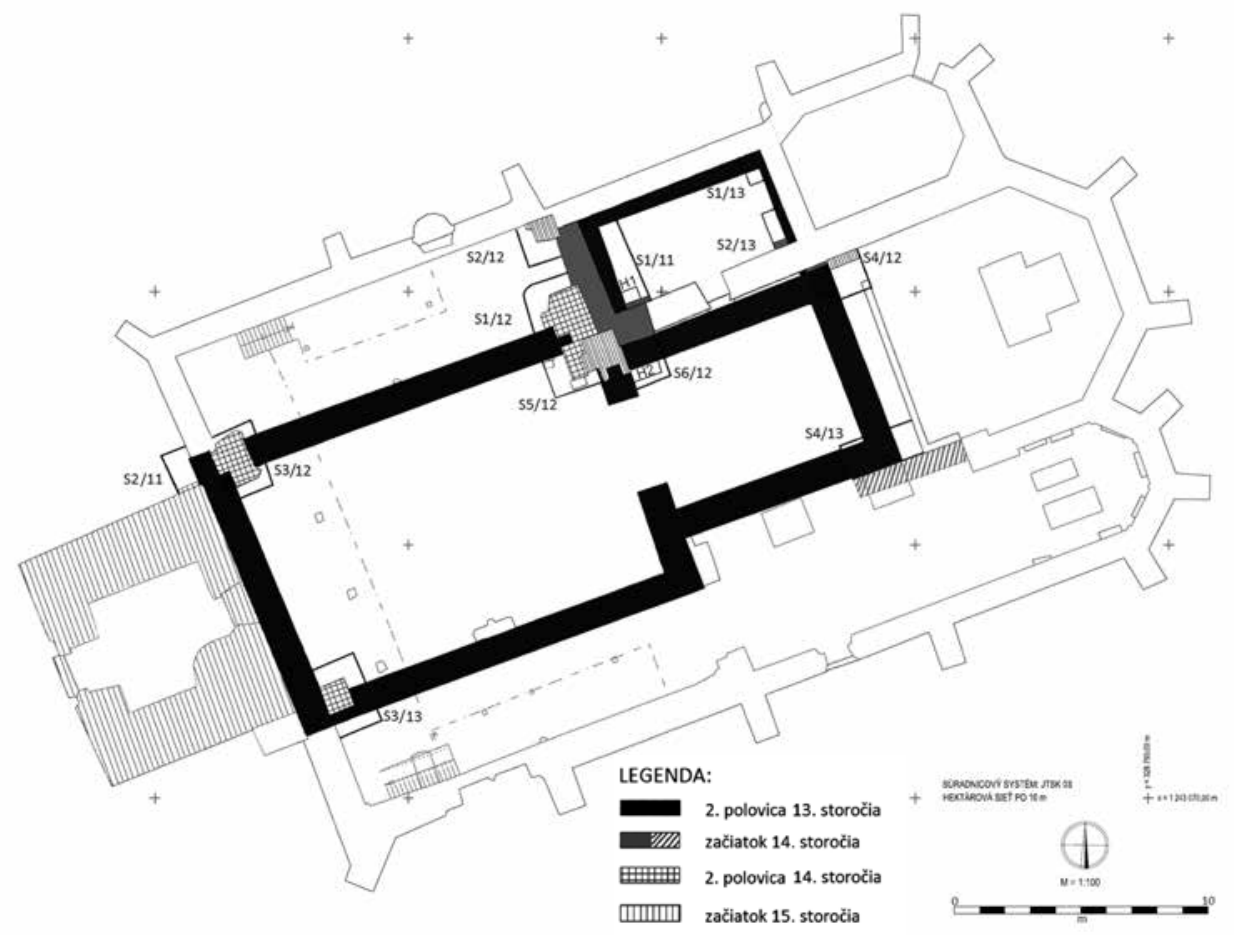

Obr. 3. Etapizácia stavebného vývoja archeologicky preskúmaných murív kostola. Autor P. Tajkov.

Fig. 3. Phases of the building development of the archeologically investigated church masonry. Drawing P. Tajkov. 


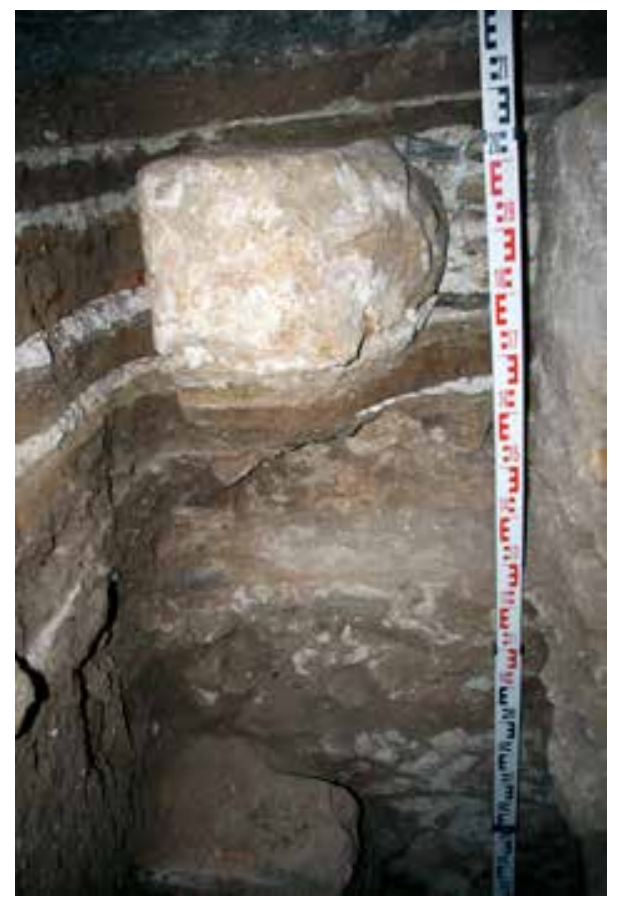

Obr. 4. Sonda S5/12 - severný profil so zvyškami historických podláh a základovým i čiastočne nadzákladovým severným múrom pôvodnej lode. Foto A. Balogh.

Fig. 4. Test pit S5/12 - north profile with remains of historical floors, the foundation and partially also super-structure north wall of the original nave. Photo A. Balogh. kostola (napr. pätky pilierov a pilastrov), zakryté novovekými podlahovými úpravami.

Väčšinu zachytených vrstiev možno interpretovat' ako planírky, navážky, resp. často ako podkladové vrstvy pre dlážky. Podobne aj výkopy možno interpretovat' bud' ako stavebné jamy, ale poväčšine skôr ako viacnásobné hrobové jamy. Čo sa týka murovaných konštrukcií, boli zachytené jednak murivá zaniknutých stavieb, jednak preskúmané dodnes stojace murivá a vzt’ahy medzi nimi, spolu so vzt’ahmi k historickým podlahám.

Z pohladu archeologického výskumu je teda možné do istej miery zrekapitulovat' stavebný vývoj preskúmaných častí kostola. Nateraz najstaršou známou stavebnou etapou dnešného evanjelického kostola bola jednolod’ová stavba s pravouhlým presbytériom a naraz pristavanou sakristiou na severnej strane (obr. 3). V sondách S1 a S5/12 (obr. 4) a v sondách $\mathrm{S} 3 / 12$ a $\mathrm{S} 3 / 13$ boli zachytené zvyšky severného múru lode aj napojenie na dodnes čiastočne stojace západné murivo lode. V sonde S3/13 (obr. 5) bola objavená aj čast' osekaného muriva previazaného s bývalým juhozápadným nárožím lode, ktoré interpretujeme ako zvyšky zrejme dodnes čiastočne stojaceho oporného piliera (medzi dnešnou vežou a južnou lod'ou). V sonde S2/11 v exteriéri kostola

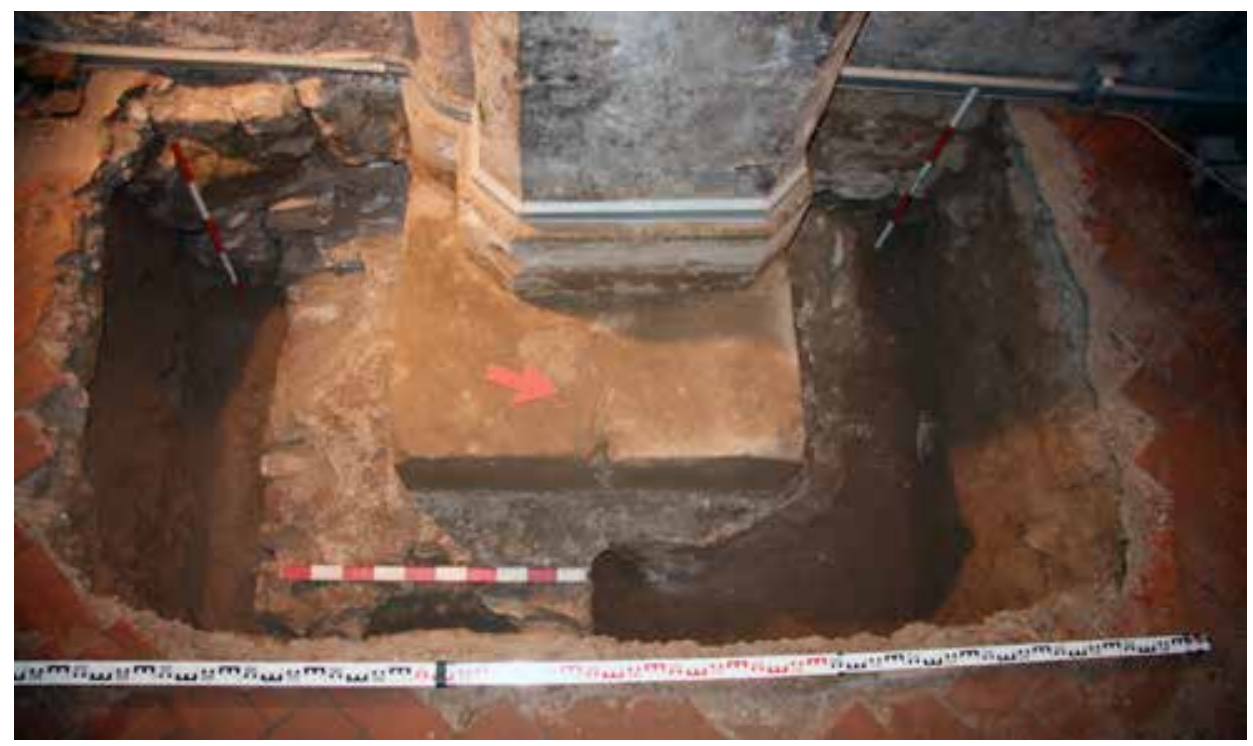

Obr. 5. Sonda S3/13 - základové murivo JZ rohu pôvodnej lode aj so zvyškami osekaného oporného piliera. Foto A. Balogh. Fig. 5. Test pit S3/13 - masonry foundations of the SW corner of the original nave with remains of a supporting pillar. Photo A. Balogh. 


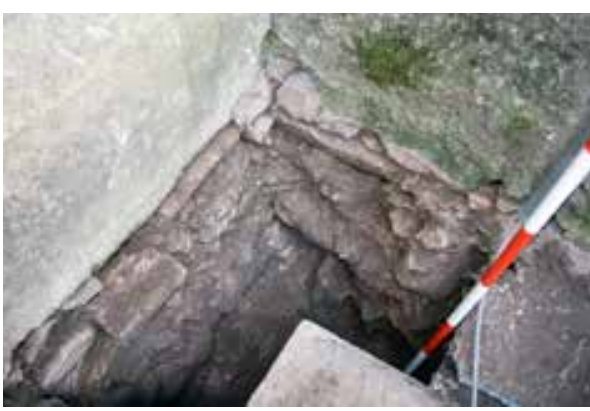

Obr. 6. Sonda $S 2 / 11$ - cezúra v základovom murive medzi lod'ou a vežou kostola. Foto A. Balogh.

Fig. 6. Test pit S2/11 - gap in the masonry foundations between the nave and the church tower. Photo A. Balogh.

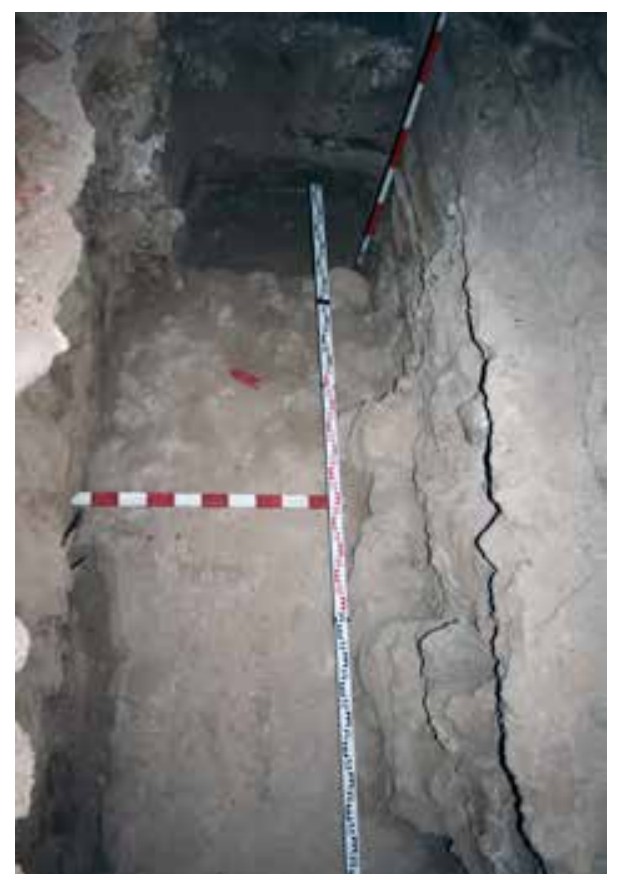

Obr. 7. Sonda S4/13 - základové murivo, juhovýchodné nárožie svätyne pôvodného kostola. Foto A. Balogh.

Fig. 7. Test pit S4/13 - masonry foundations, SE corner of the chancel of the original church. Photo A. Balogh. sme zdokumentovali cezúru medzi západným murivom pôvodnej lode a neskôr pristavanou vežou kostola (obr. 6). V sonde S6/12 sme zachytili severné murivo presbytéria aj so základom vít'azného oblúka (obr. 9), v sonde S4/12 vonkajšie severovýchodné nárožie pôvodnej svätyne a v sonde $\mathrm{S} 4 / 13$ aj jeho vnútorné i vonkajšie juhovýchodné nárožie (obr. 7). V sondách S1/11, S1/13 a S2/13 sme zachytili základové murivá pôvodnej sakristie kostola, na ktorých čiastočne stojí dnešná sakristia a ku ktorým bolo neskôr pristavané murivo druhej fázy svätyne kostola. Takto sme mohli spol'ahlivo rekonštruovat' celý pôdorys nateraz najstaršej známej podoby štítnického kostola. Je však dôležitým faktom, že základové murivo vít’azného oblúka i sakristie porušuje, resp. stojí na starších hroboch, čo naznačuje existenciu ešte staršej sakrálnej stavby, či aspoň vysvätenej pôdy cintorína (obr. 8-11). Najstaršiu stavebnú etapu dnešného kostola možno na základe pôdorysnej dispozície považovat' za ranogotickú stavbu. $Z$ toho vyplýva aj náš návrh jeho datovania len širšie do druhej polovice 13. storočia.

Možno už o generáciu či dve neskôr došlo $\mathrm{k}$ prvej prestavbe kostola. $\mathrm{V}$ rámci tejto druhej stavebnej etapy zbúrali pôvodnú pravouhlú svätyňu aj so sakristiou a nahradili ju o niečo širším presbytériom, pravdepodobne s polygonálnym uzáverom. Zbúrané základové murivo pôvodnej svätyne tak obstavali z vonkajšej strany a základové murivo sakristie čiastočne využili. Zvyšky tejto svätyne dodnes stoja a tvoria severný múr chórovej časti presbytéria kostola. Archeologicky sme v sonde S4/13 preskúmali aj zvyšky jej severného múru so zachovanou omietkou (obr. 12). Z tejto stavebnej etapy stojí v pôvodnom pôdoryse dnešná sakristia, ktorej západné a východné murivo však už teraz tvorí východný uzáver severnej lode a západný uzáver tzv. kostnice kostola. Približne v híbke jedného metra pod úrovňou dnešnej podlahy sme $\mathrm{v}$ tomto murive objavili aj stopy po bývalom exteriérovom vstupe do sakristie zo západu (obr. 13). Túto stavebnú etapu možno datovat' len rámcovo do začiatku 14. storočia a tak hypoteticky spojit's novými pomermi po rozdelení ákošovského majetku.

$\mathrm{K}$ doteraz najstarším stavebným fázam kostola prirad’ujeme aj zvyšky najstarších dlážok zachytených výskumom (obr. 14). K prvej stavebnej etape náležia zvyšky maltových lôžok dlážky viažuce sa k základovým odskokom pôvodnej lode, svätyne i sakristie (približne $1 \mathrm{~m}$ od dnešnej úrovne podlahy). Zvyšky o niečo vyššie zachovanej dlážky sa už viažu k obdobiu po rozšírení, resp. nahradení staršieho pravouhlého presbytéria väčším a rovnako aj s novou, dodnes stojacou sakristiou. 


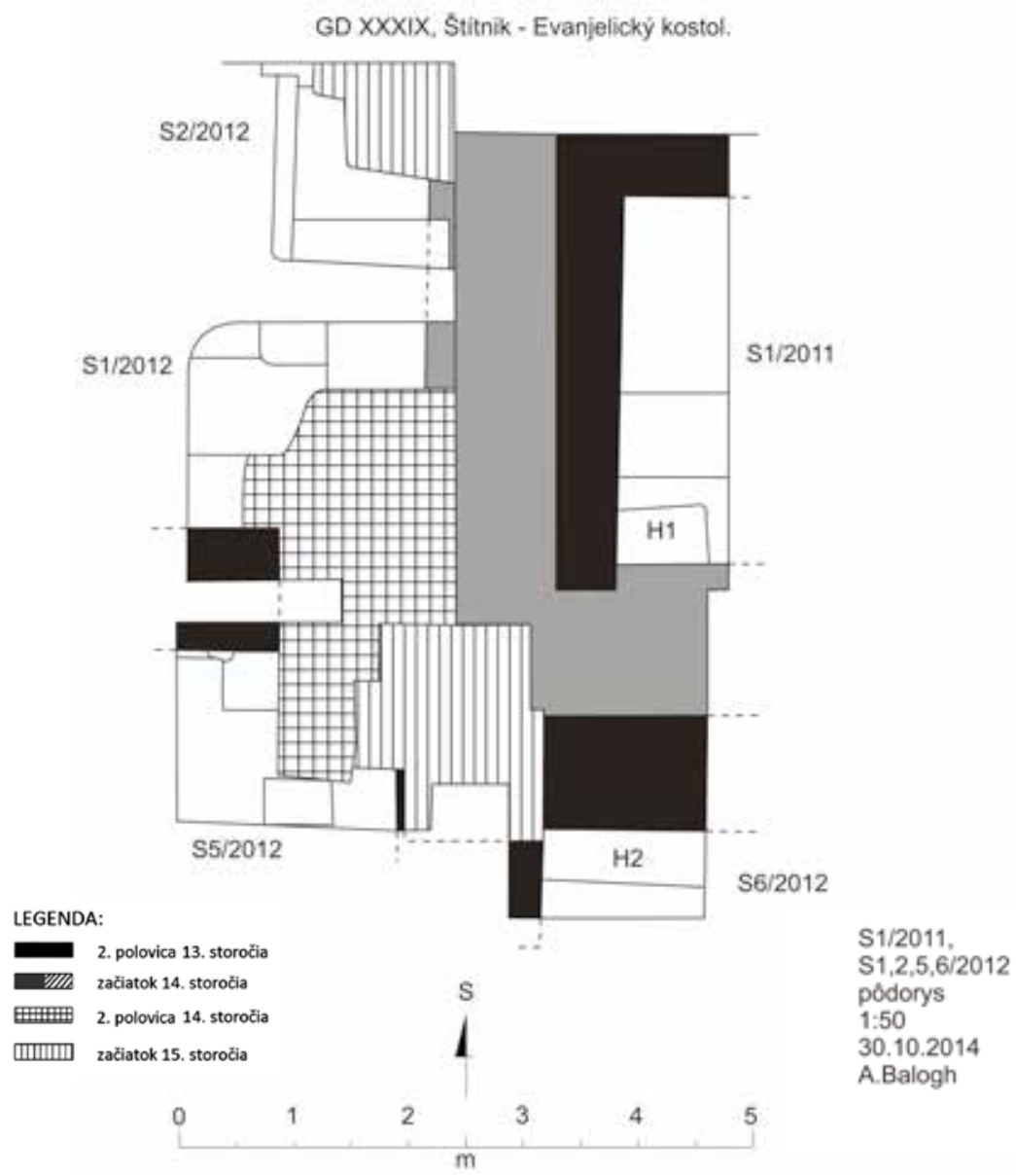

Obr. 8. Pôdorysy sond S1/2011, S1/2012, S2/2012, S5/2012, S6/2012. Autor A. Balogh.

Fig. 8. Ground plans of test pits S1/2011, S1/2012, S2/2012, S5/2012, S6/2012. Drawing A. Balogh.

Čo sa týka bazilikálnej prestavby kostola, táto je zvyčajne spájaná s udalost’ami nasledujúcimi po roku 1328, kedy Štítnik získal mestské výsady (Skalská 2009, 154). Archeologicky sme preskúmali murivo severnej lode a základy pilastrov nesúcich arkády oddel'ujúce trojlodie. Tieto pilastre a piliere boli postavené na základovom murive lode pôvodného kostola (S3/12, S3/13). Piliere oddel'ujúce chórovú čast' dnešného kostola od južnej lode zas stoja na základoch svätyne z druhej stavebnej etapy (S4/13). K tejto prestavbe sa už viažu zvyšky d’alšej dlážky, ktoré v sonde S3/12 prekrývali, resp. ležali priamo na korune zbúraného muriva pôvodného kostola. $\mathrm{K}$ presnejšiemu datovaniu tejto rozsiahlej prestavby sa nedokážeme vyjadrit', zjavne však k nej nedošlo naraz. Situácia v severnej lodi (S2/12) poukazuje napr. na dodatočné postavenie pilastra podopierajúceho klenbu. Autori architektonicko-historického výskumu uvádzajú postavenie najprv severnej lode, potom južnej a následne južného chóru s postupným zaklenutím týchto priestorov od druhej štvrtiny 14. storočia cez jeho záver až po polovicu 15. storočia.

Poslednou výraznou stavebnou úpravou, ktorej sa dotkol náš výskum, bola výstavba dnešného vít'azného oblúka a prestavba presbytéria kostola do dnešnej podoby. Podl'a autorov architektonicko-historického výskumu tieto stavebné úpravy prebehli od začiatku 15. storočia. V sondách S5/12 a S6/12 sme zdokumentovali pristavanie severnej časti vít’azného oblúka 


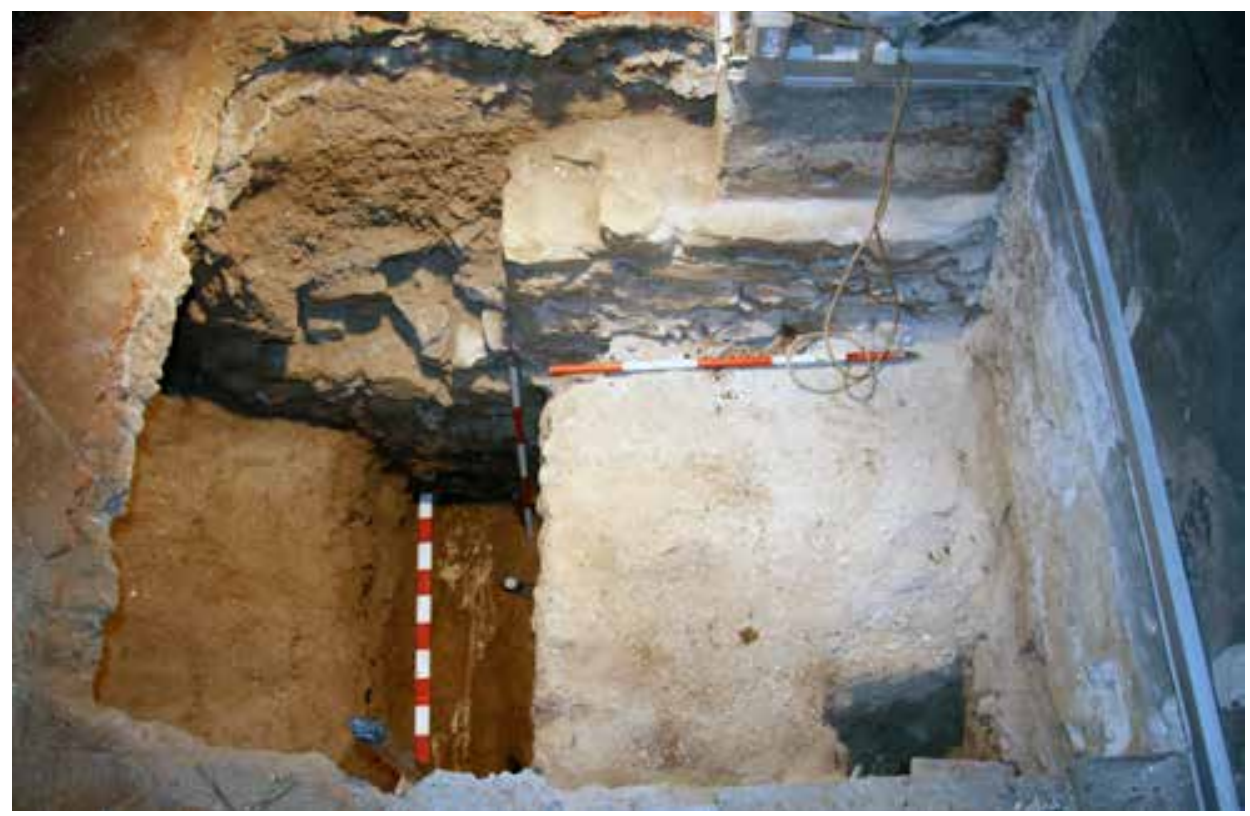

Obr. 9. Sonda S6/12 - základové murivo svätyne a vít’azného oblúka pôvodného kostola, stojaceho na staršom hrobe. Foto A. Balogh.

Fig. 9. Test pit S6/12 - masonry foundations of the chancel and triumphal arch of the original church erected over an older grave. Photo A. Balogh.

$\mathrm{k}$ pilastru arkády medzi severnou a hlavnou lod'ou a k murivu druhej etapy svätyne kostola - to všetko s využitím základov pôvodného kostola. V sonde S4/12 sme potvrdili v základoch cezúru $\mathrm{v}$ nadzemnom murive medzi prístavbou dnešného presbytéria $\mathrm{k}$ murivu jeho staršej stavebnej etapy. Na záver sa dotknime mohutnej západnej veže kostola, ktorú autori spomínaného výskumu považujú za pôvodne samostatnú stavbu a predpokladajú jej vznik už v prvej polovici 13. storočia (Klingová et al. 2014). V ich sonde v severnej špalete vstupu z veže do lode kostola zachytili obhorené murivo s lícovaným povrchom, ktoré podl'a nich dokladá, že išlo o exteriérovú omietku staršieho muriva veže a ktoré bolo neskôr obmurované. Tomu však odporuje situácia v našej sonde S2/11, kde cezúra v základovom murive pôvodnej lode kostola a veže jednoznačne poukazuje na jej neskoršiu prístavbu. Jej základové murivo je tu dokonca pristavané k pôvodne nadzemnému murivu kostola, resp. priamo k jeho exteriérovému soklu. To znamená, že v čase jej výstavby už výrazne narástla úroveň terénu dôsledkom pochovávania alebo úprav blízkej cesty. Situáciu v spomínanej sonde architektonicko-historického výskumu možno však interpretovat' aj na základe našej sondy S3/12, kde je zretel'né, že túto neskoršiu obmurovku získalo aj nadzemné západné murivo najstaršej fázy kostola, pravdepodobne po jednom z jeho požiarov. Nie je teda vylúčené, že k výstavbe veže nedošlo o niečo skôr a zachytené lícované murivo patrilo pôvodne interiéru kostola. Tzv. plentáže murív sú bežnou praxou pri prestavbách a obnovách kostolov, avšak do úrovne základových cezúr objektov spravidla nezasahujú. Samozrejme, lepšie zodpovedanie otázok spojených s výstavbou veže kostola by mohol priniest’ až jej detailnejší výskum.

Čo sa týka nálezov menších murovaných konštrukcií v sondách S1, S2, S4 a S5/12, ich nálezové okolnosti jasne naznačujú, že všetky pochádzajú ešte zo stredoveku a interpretujeme ich ako zvyšky bočných oltárov. Až do obdobia novoveku možno zaradit' posledné štyri podlahové úpravy kostola, ktoré poväčšine prekrývajú stredoveké tvaroslovie murovaných konštrukcií kostola. V tomto období už boli odstránené aj spomínané bočné oltáre kostola, čo zaiste súviselo 
GD XL, Stitnik - Evanjelický kostol.

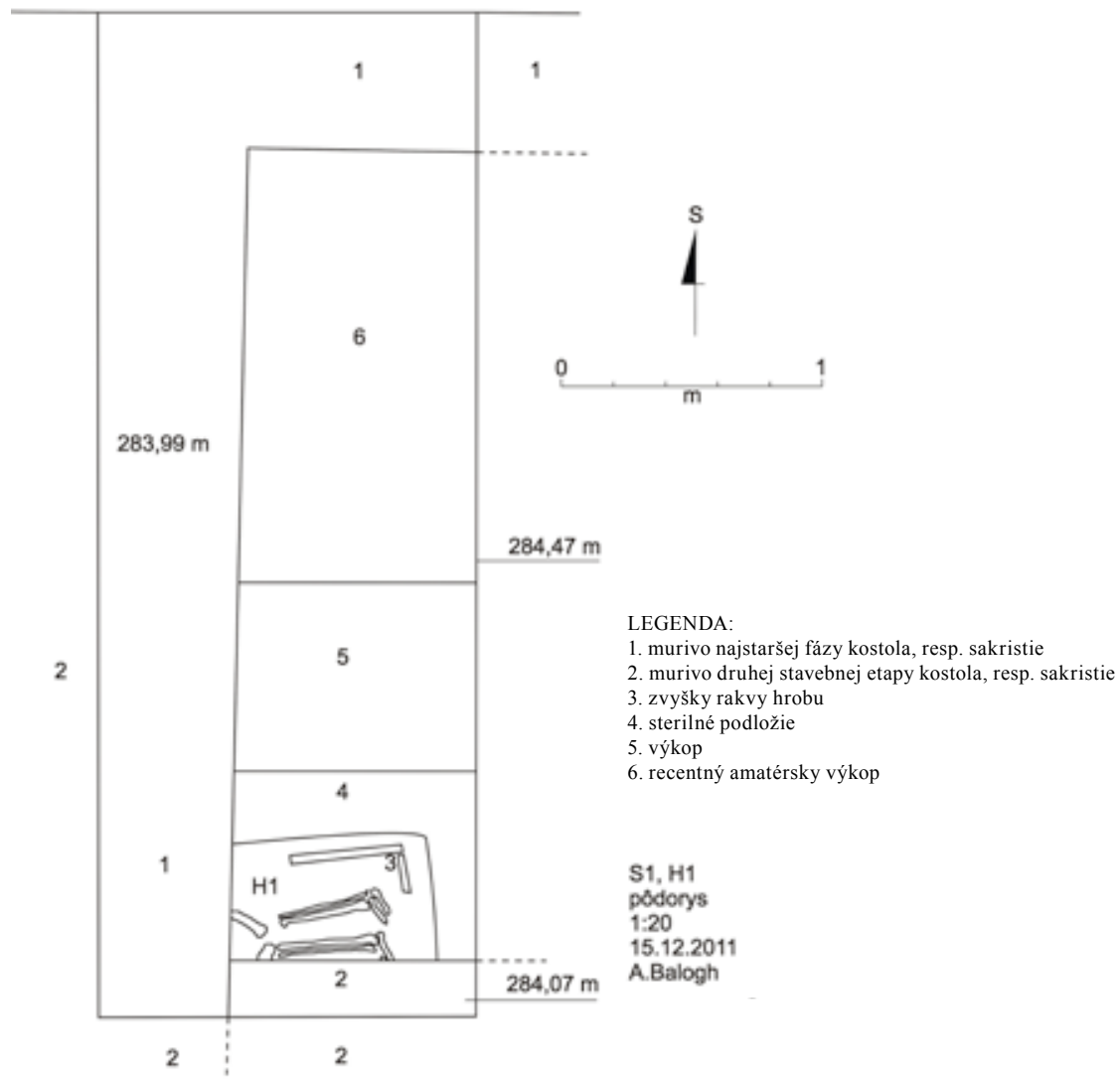

Obr. 10. Sonda S1/2011 - pôdorys. Autor A. Balogh.

Fig. 10. Test pit S1/2011 - ground plan. Drawing A. Balogh.

GD XLI, Stitnik - Evanjeticky kostol.
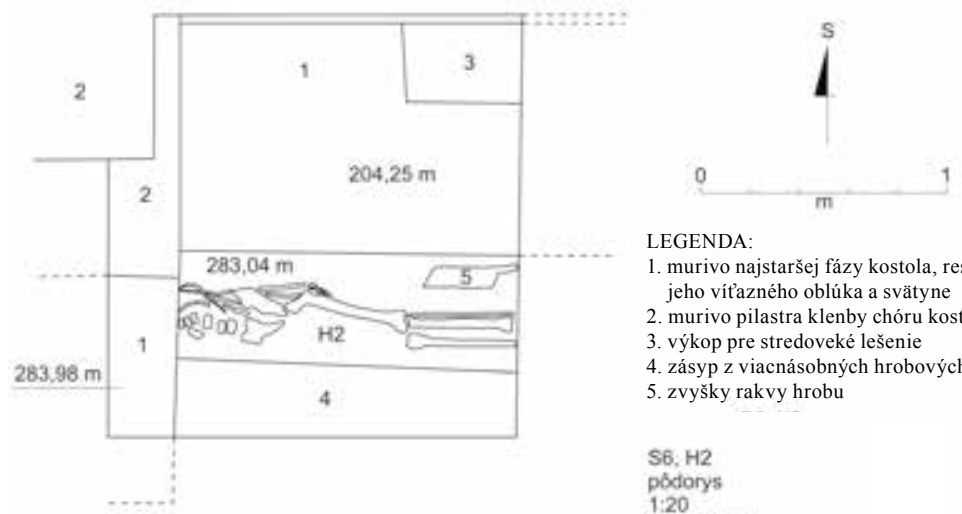

LEGENDA:

1. murivo najstaršej fázy kostola, resp. základu jeho vítazného oblúka a svätyne

2. murivo pilastra klenby chóru kostola

3. výkop pre stredoveké lešenie

4. zásyp z viacnásobných hrobových jám

5. zvyšky rakvy hrobu

S6. H2

pótorys

1:20

21.11 .2012

Obr. 11. Sonda S6/2012 - pôdorys. Autor A. Balogh.

A.Balogh

Fig. 11. Test pit S6/2012 - ground plan. Drawing A. Balogh. 


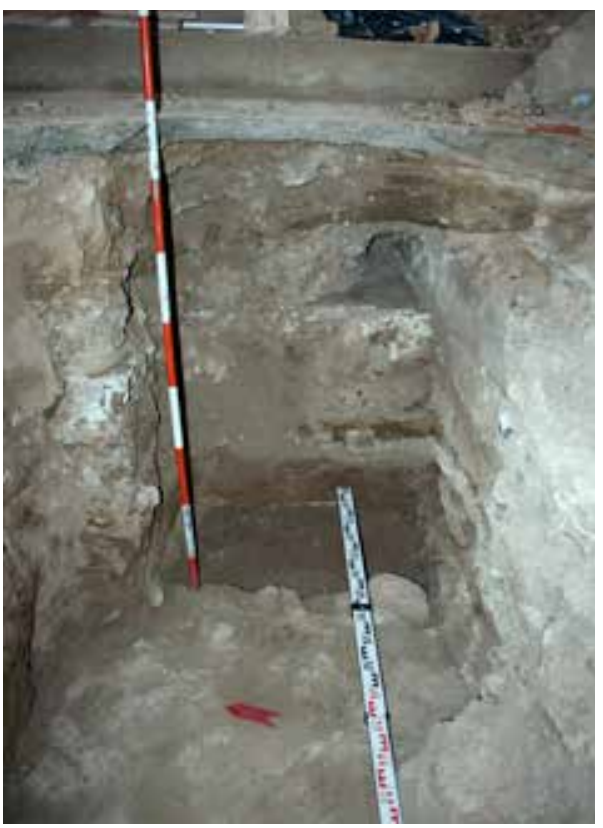

Obr. 12. Sonda $S 4 / 13$ - juhovýchodný roh svätyne pôvodného kostola so zvyškami tzv. druhej svätyne v južnom profile aj so zachovanou omietkou. Foto A. Balogh.

Fig. 12. Test pit $S 4 / 13$ - SE corner of the chancel of the original church with remains of a "second" chancel in the south profile, with preserved plaster. Photo A. Balogh.

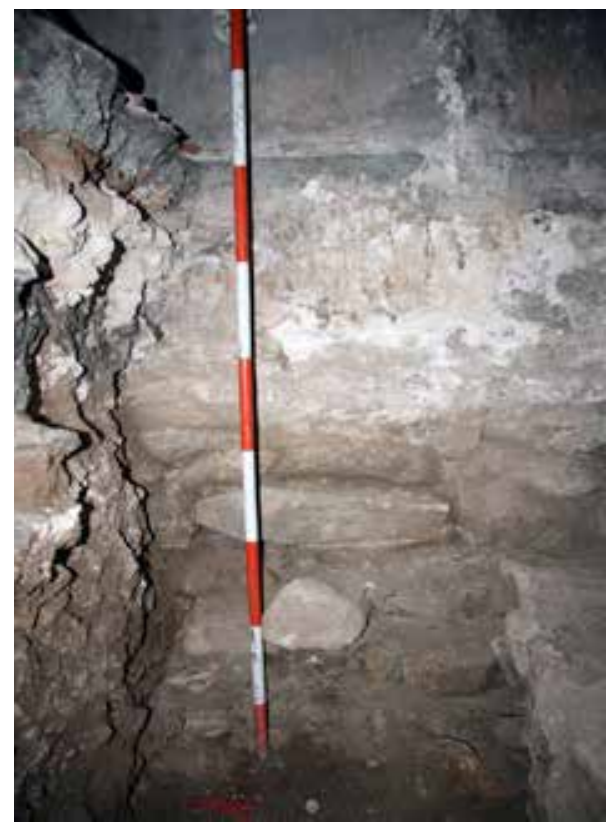

Obr. 13. Sonda S1/12 - východný profil a prahový kameň pôvodného vstupu do sakristie z exteriéru. Foto A. Balogh. Fig. 13. Test pit $S 1 / 12$ - east profile and a threshold stone from the original entrance to the sacristy. Photo A. Balogh.
S užívaním kostola evanjelikmi od roku 1590. Čo sa týka pochovávania, výskum okrem dvoch najstarších hrobov predchádzajúcim postaveniu pôvodného kostola zachytil množstvo hrobových jám a zvyškov l'udských kostí.

Nevýrazné hnutel'né nálezy výskumu poväčšine pochádzajú zo zásypov výkopov, v menšej miere z vrstiev a možno ich rozdelit' do niekol'kých skupín. Najviac nálezov tvoria črepy kuchynskej keramiky. Okrem niekol'kých črepov z malovaných tanierov dominujú úlomky tenkostenných svetlých džbánov, niekedy s červenkastou lineárnou mal'ovanou výzdobou a vnútornou žltkastou, hnedastou alebo zelenkavou glazúrou. Túto keramiku možno rámcovo datovat' do obdobia včasného novoveku.

K početným nálezom patrí aj stavebná keramika $\mathrm{v}$ podobe tehlových dlaždíc, ktoré tvorili povrchovú úpravu všetkých historických podláh kostola (okrem poslednej drevenej v sakristii). Niektoré sa nám podarilo zachytit' in situ, staršie dlaždice však pochádzajú len zo sekundárnej polohy $\mathrm{v}$ zásypoch výkopov. Novoveké podlahy mali heterogénny charakter a pozostávali aj zo starších, sekundárne použitých dlaždíc. Zvlášt' tu možno upozornit' na tri konkrétne typy. K najmladším patria príklady fragmentov perforovaných dlaždíc zachytených in situ $\mathrm{v}$ úrovni historickej podlahy. Podl'a odborného posudku M. Čurného (2013) možno tieto dlaždice datovat' najskôr do konca 18. storočia, resp. do prvej polovice 19. storočia (obr. 15). Ide o dlaždice formátu zhruba $29 \times 29 \times 2,5-3 \mathrm{~cm}$ zo zmiešanej hliny bieloružovej a bieločervenkastej farby, opatrené z oboch strán viacerými radmi drobných dierok $\mathrm{s}$ priemerom okolo $0,5 \mathrm{~cm}$, pričom ide zásadne o neúplné perforácie. Vzhl'adom na poznatky o niektorých produkčných tehliarskych strediskách na južnom Slovensku sa ukazuje, že by mohlo íst' o výrobky z novohradských, resp. západogemerských tehelní, pričom do úvahy prichádza najmä Poltár a Lučenec s okolím. Tu sa nachádzali a aj intenzívne využívali ložiská kaolinitických ílových hlín prevažne bielej, okrovej, ale aj ružovkastej farby.

Z oblasti Poltára, Lučenca, Rimavskej Soboty, ale aj iných regiónov poznáme niekol'ko lokalít, odkial' pochádzajú archeologické nálezy takýchto dlaždíc (Lučenec - Reduta, 
GD XVIII, Stitnik - Evanjelickỹ kostol.

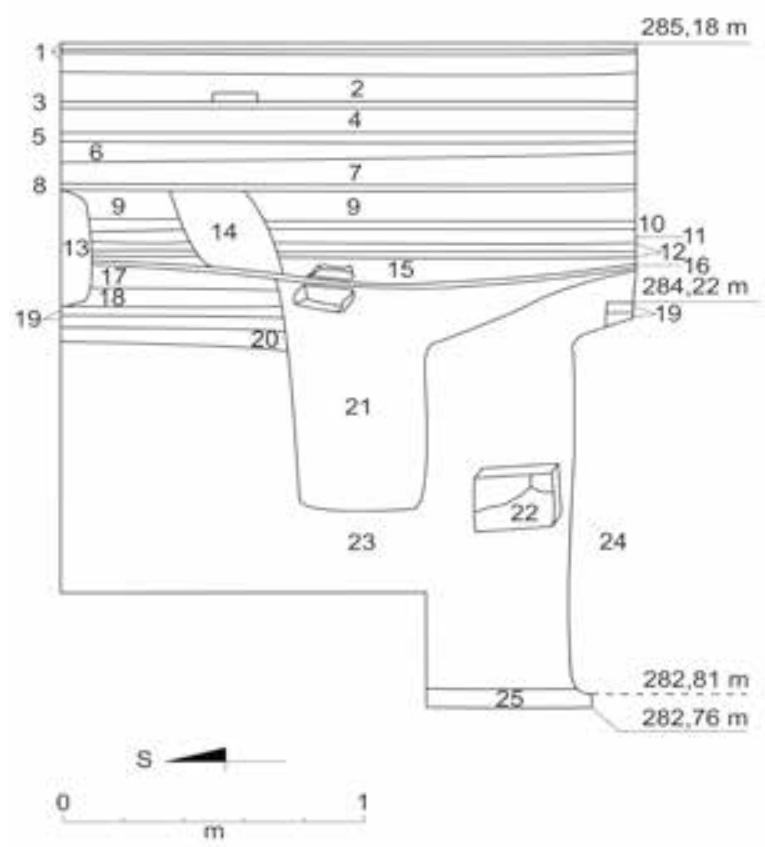

LEGENDA:

1. súčasná podlaha kostola pozostávajúca z tehlového prefabrikátu a betónového podkladu, pochádzajúca z roku 1909

2. navážka jemnej stavebnej sutiny

3. pôvodne novoveká keramická podlaha v maltovom lôžku

4. hlinitá navážka

5. pôvodne novoveká keramická podlaha v maltovom lôžku

6. hutná ílovitá navážka

7. navážka s prímesou jemnej sutiny

8. pôvodne neskorostredoveká keramická podlaha v maltovom lôžku

9. hutná hlinitá navážka

10. pôvodne stredoveká keramická podlaha v maltovom lôžku

11. hutná hlinitá navážka

12. pôvodne stredoveká keramická podlaha v maltovom lôžku

13. nešpecifikovaný výkop

14. nešpecifikovaný výkop

15. hlinitá navážka s maltovinou a uhlíkmi

16. maltovinová navážka

17. žltohnedá hlinitá navážka

18. hlinitá navážka s uhlíkmi

19. pôvodne stredoveká dlážka zaniknutého kostola

20. hlinitá vrstva s uhlíkmi

21. pôvodne hrobová jama

22. opracovaný kamenný kváder

23. viacnásobné hrobové výkopy

24. murivo lode pôvodného zaniknutého kostola

25. štrkovo-ílovité sterilné podložie

\section{$\mathrm{S} 5$}

zâpadrí profil

$1: 20$

27.03 .2012

A. Balogh

Obr. 14. Sonda S5/2012 - západný profil. Autor A. Balogh.

Fig. 14. Test pit S5/2012 - west profile. Drawing A. Balogh.

Divín - hrad, Modrý Kameň - hrad), resp. sú doposial’ známe v pôvodných polohách - in situ (Ozdín - evanjelický kostol, Modrý Kameň - hrad). Skúmané dlaždice patria do skupiny tzv. bielej stavebnej keramiky (dlaždice, strešná krytina), ktorá ešte nebola podrobne vyhodnotená. Zatial' sa dá vychádzat' iba z poznatkov o tehliarstve $\mathrm{v}$ tejto oblasti $\mathrm{v}$ mladšom novoveku až 20. storočí, ktorého produkcia sa pri dlaždiciach a strešnej krytine zameriavala na využívanie najmä týchto bielych tehliarskych hlín (Čáni 2011; Čurný 2008). Rozvoj bielej stavebnej keramiky sa dá spájat' až s 19. a 20. storočím. Z tohto obdobia disponujeme zmienkami o tehliarskej výrobe v uvedenom regióne. Čo sa týka bielych dlaždíc, tradovalo sa, že pochádzajú z keramickej továrne baróna Barattu v Poltári (založil ju v roku 1862 Ritten von Rittestein, ktorý ju o rok na to predal barónovi Aloisovi Barattovi-Dragano). V roku 1882 boli otvorené jej pobočky - Hôrka a Turbína v Zelenom. Tehelne neskôr prevzal jeho syn Norbert. Za jeho vedenia sa poltárska prevádzka stala priemyselným podnikom, ktorý zamestnával 250-300 robotníkov; Korimová 2002, $142,143)$. Výrazným typom dlaždíc zachovaných rovnako v pôvodnej polohe $(19 \times 18 \times 4 \mathrm{~cm})$ sú pomerne mohutné, skoro štvorcové dlaždice s mierne skosenými hranami, ktoré možno datovat' na základe ich spojenia so základovým odskokom dnešného vítazného oblúka do obdobia poslednej neskorostredovekej prestavby kostola. Posledným typom dlaždice je menšia $(15 \times 15 \times 3,5 \mathrm{~cm})$ dlaždica so stopami zelenkavej glazúry, ktorá pôvodne prekrývala rytú výzdobu s t’ǎko rekonštruovatel’ným motívom. V rámci slovenského prostredia ide podla M. Čurného o výnimočný nález (Čurný 2013; obr. 16). Glazované dlaždice poznáme z Bratislavského hradu, neskorý stredovek, Filakovského hradu, 16.-17. storočie (Čurný 2008, 205, 206, obr. 64), hradu Strečno, 17. storočie (Čurný 2008, 218, 219, obr. 73) a hradu Parič v Trebišove, 17.-18. storočie (Čurný 2008, 226). Fragment glazovanej zdobenej dlaždice bol zistený aj počas archeologického výskumu Kostola sv. Demetra v Ražňanoch, okr. Sabinov (Luštíková-Čurný 2011). Tu evidentne 


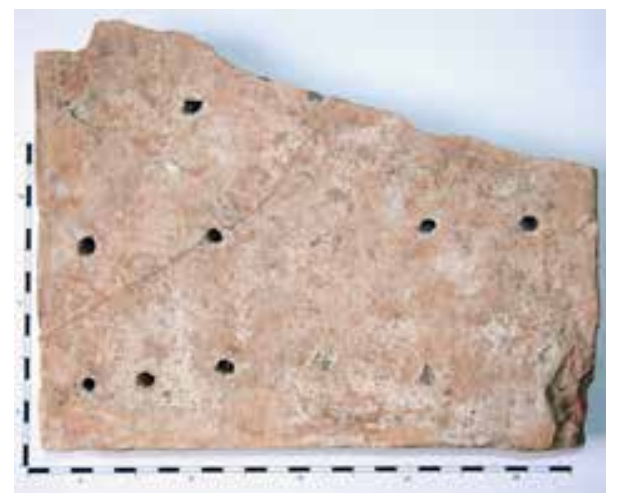

Obr. 15. Novoveká dlaždica z bývalej podlahy kostola. Foto A. Balogh.

Fig. 15. Modern-age tile from the church floor. Photo A. Balogh.

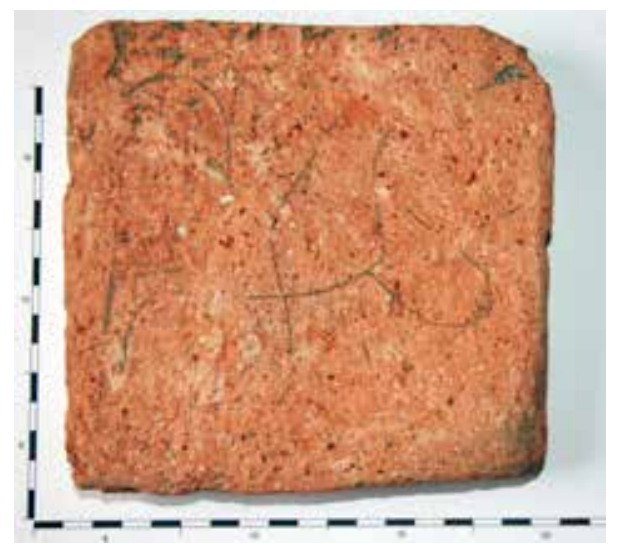

Obr. 16. Stredoveká dlaždica $z$ bývalej podlahy kostola. Foto A. Balogh.

Fig. 16. Medieval tile from the church floor. Photo A. Balogh. súvisí s najstaršou fázou kostola, ktorú možno vymedzit' obdobím od 30. rokov 14. storočia po rok 1510. Nález glazovanej dlaždice zo Štítnika predstavuje spolu s dlaždicou z Ražnian osobitnú skupinu, nakol'ko použitie glazúry pri nich plnilo d’alšiu dekoračnú funkciu. V keramickej hmote na lícnej strane dlaždice sa nachádzal negatív výzdoby v podobe bud' vtlačených plôch, alebo rytia, rýh. Transparentná glazúra tieto miesta prekrývala, čím bol dosiahnutý zdobiaci efekt tak, že hlbšie plochy vyznievali tmavšie a vlastne kontúrovali výzdobný motív. Ten však nie je možné predbežne rekonštruovat', nakol'ko sa z výzdoby zachovali iba neúplné sekvencie. Na zlom stave zachovania sa podpísalo zrejme slabšie finálne zvládnutie prípravy glazúry a snád' aj výpalu. $Z$ tohto dôvodu glazúra z väčšej časti lícnej strany jednoducho opadala, k čomu zrejme mohlo prispiet' dlhodobé deponovanie vo vlhkom prostredí. Iba po bokoch (na profiloch) sa zachovali celistvejšie plochy s glazúrou, na základe ktorých je zrejmé, že glazúra bola aplikovaná priamo na črep dlaždice, engoba použitá nebola.

Nález glazovanej dlaždice zo Štítnika nie je možné dostatočne porovnávat', nakol'ko tento druh materiálnej kultúry z oblasti stavebnej keramiky v našom nálezovom prostredí takmer úplne absentuje. Iba v posledných rokoch sa zistili prvé nálezy (Ražňany), resp. boli objavené v starších zbierkových fondoch (Bratislavský hrad). Na základe rozmerov dlaždicu nemožno presnejšie datovat', nakol'ko tento rozmer nie je známy ani z nálezov, ani $\mathrm{z}$ in situ situácií. Podla M. Čurného sa ukazuje, že rozmery štvorcových dlaždíc so stranami menšími ako $17-18 \mathrm{~cm}$ sú typické skôr pre obdobie pred koncom 15. storočia, odkedy zaznamenávame dlaždice väčších rozmerov a s inak vytvarovanými profilmi, pričom glazúru zaznamenávame len výnimočne. Zdobenú glazovanú dlaždicu zo Štítnika možno predbežne datovat' do 14. storočia.

V západnej časti kostola sme zachytili aj niekol'ko mincí, ktoré boli vyrazené v období medzi rokmi 1705-1800. K pozoruhodnejším náleží tzv. libertáš Františka Rákoczyho II. K medeným ozdobám patrí aj šest' kusov pukličiek v tvare polmesiaca, pravdepodobne pôvodne z rakvy, ktoré datujeme len rámcovo do novoveku. Kovové nálezy, resp. ich súčasti, tvorili aj časti odevov ako čast' drôtenej krajky, či podobnou krajkou ozdobená čast' pohrebného rubáša - opät' pravdepodobne pochádzajúce až z novoveku. K stredovekým nálezom prirad’ujeme fragment profilovanej, pôvodne polychrómovanej kamennej sväteničky.

\section{Záver}

Možno teda konštatovat', že náš výskum ozrejmil nateraz najstaršiu známu podobu pôdorysu štítnického kostola. Predpokladáme však aj existenciu ešte staršieho sakrálneho objektu, 
ktorý indikujú spomínané hroby pod murivom najstarších základov kostola. Preskúmaný pôdorys tejto pomerne vel'kej stavby, s najväčšou pravdepodobnost'ou už aj s oporným systémom, svedčí o jeho vzniku niekedy v druhej polovici 13. storočia. Zrejme od roku 1320 až do konca stredoveku je už kostol predmetom mimoriadnej stavebnej aktivity nového rodu pánov zo Štítnika. Aj náš výskum naznačuje, že skoro každá generácia tejto rodiny prostredníctvom vel'korysých stavebných úprav ciel’avedome napíňala víziu reprezentatívneho chrámu a zároveň rodovej hrobky. To platí najmä o postupnej rozsiahlej bazilikálnej prestavbe, počas ktorej istý čas slúžila lod' pôvodného kostola. Ani tzv. druhé, pravdepodobne polygonálne presbytérium nebolo zbúrané naraz. Podobne ako dodnes stojí jeho severná stena, jeho južná stena stála až do prístavby chóru južnej lode. Základy pilierov arkády oddel'ujúce oba priestory stoja na zvyškoch jeho omietaného, pôvodne nadzemného muriva. To referuje, ako výrazne sa už v stredoveku menili výškové pomery interiéru kostola $\mathrm{v}$ dôsledku navyšovania sutinových vrstiev a intenzívneho pochovávania. To platí zaiste i pre jeho exteriér, kde boli základy neskorogotickej veže pristavané k pôvodne nadzemnému murivu kostola. Žial', výskum exteriéru kostola je aj do budúcnosti vel’mi obmedzený kvôli nefunkčnej mohutnej betónovej konštrukcii drenáže z 80 -tych rokov minulého storočia.

Náš doterajší archeologický výskum, vzhl'adom na rozmery chrámu, možno považovat' len za parciálny. Napriek tomu snád' pomôže doplnit' historický obraz o štítnickom kostole ako o dynamicky sa rozvíjajúcom stredovekom architektonickom diele, umocnenom výnimočnou maliarskou výzdobou. Od jeho poslednej komplexnej obnovy však už ubehlo viac než storočie a na d’alšiu tento tak trochu stratený klenot slovenskej sakrálnej architektúry, bohužial', stále čaká.

Príspevok vznikol v rámci projektu 1/0727/17 vedeckej agentúry VEGA.

\section{Literatúra}

ČÁNI, J., 2011: Tehelne severného Novohradu. Referát prednesený na 3. stretnutí znalcov a zberatel'ov historických tehál, organizovanom Spoločnostou pre výskum histórie tehliarstva, Laterãrius, Bratislava, SNM - Archeologické múzeum, 5. 11. 2011.

ČURNÝ, M., 2008: Tehla ako stavebný materiál stredovekej a novovekej architektúry na Slovensku. Pohl’ad archeológa. Dizertačná doktorandská práca. Nitra: Archeologický ústav SAV.

- 2013: Štítnik. Dlaždice z evanjelického kostola (pôvodne katolíckeho, vysväteného Blahoslavenej panne Márii). In: Tajkov, P., Archeologický výskum kostola ev. a. v. v Štítniku. Technická univerzita v Košiciach, rkp. ulož. v Krajskom pamiatkovom úrade Košice.

DVOŘÁKOVÁ, V.-KRÁSA, J.-STEJSKAL, V., 1978: Stredoveká nástenná mal'ba na Slovensku. Praha.

KAHOUN, K., 1970: Gotická architektúra na Slovensku, Ars 4, 1-2, 45-74.

KLINGOVÁ, A. et al., 2012: Pamiatkový výskum architektonicko-historický a umelecko-historický, NKP kostol ev. a. v., č. ÚZPF 638/0, Teplická ulica, Štítnik, 2011-2012, rkp. ulož. v Pamiatkovom úrade SR.

KLINGOVÁ, A. et al., 2014: Výsledky pamiatkového výskumu ev. a. v. kostola v Štítniku. Dostupné z: http://oz-goticka-cesta.webnode.sk/news/vysledky-pamiatkoveho-vyskumu-ev-a-v-kostola-v-stitniku/, cit. 14. 11. 2014.

KORIMOVÁ, G., 2002: Hrnčiarstvo, tehliarstvo a škridliarstvo. In: Mesto Poltár. Regionálna monografia (Alberty, J., red.), 142-147, 154. Zvolen.

LUŠTÍKOVÁ, L.-ČURNÝ, M., 2011: Ražňany - Rímskokatolícky kostol sv. Demetra. Výskumná správa č. 17520, Košice, ulož. v AÚ SAV, Nitra.

MVS: Monumenta Vaticana Slovaciae. Tomus 1. Rationes collectorum pontificiorum in annis 1332-1337 (Sedlák, V., ed.). Trnavae - Romae 2008.

PLEKANEC, V.-HAVIAR, T., 2010: Gotický Gemer a Malohont. Italianizmy v stredovekej nástennej mal'be. Martin.

POMFYOVÁ, B., 2003: Štítnik kostol ev. a. v. (heslo). In: Dejiny slovenského výtvarného umenia - Gotika (Buran, D., ed.), 643. Bratislava.

SKALSKÁ, M., 2009: Jelšava a Jelšavské panstvo v stredoveku. K osídleniu severného Gemera. Martin.

- 2010: Formovanie farskej siete v Gemerskej župe v stredoveku. In: Vývoj cirkevnej správy na Slovensku (Rábik, V., ed.), 216-229. Trnava - Kraków. 
STEINHÜBEL, J., 2016: Nitrianske kniežatstvo. Počiatky stredovekého Slovenska. Bratislava. TOGNER, M., 1989: Stredoveká nástenná mal'ba v Gemeri. Bratislava.

\section{Summary}

\section{Archaeological research into a Protestant church in Štítnik}

Štítnik was first mentioned in 1243. In 1320 the village passed to the Ákos family that was called the Štítnik (Csetneki) family from then on. In the 15th century they built a moated castle in Štítnik. The parish Church of St Mary is first mentioned in the register of papal tithes from 1332.

Archaeological research was conducted in the years 2011-2013 by the Technical University of Košice. Eleven test pits were dug in the church interior and one outside. The excavations enabled, to some extent, to chart the building history of the church. The earliest known building phase of the Protestant church is represented by a defunct single nave with a rectangular presbytery and a sacristy. It should be noted that the triumphal arch foundations and the sacristy from the first building phase were constructed on top of old graves, suggesting the existence of an even older religious building, or at least a churchyard on a consecrated plot. The ground plan of this earliest building phase of the church indicates an early Gothic building. This is related to the authors' proposal for broader dating to the second half of the 13th century. The first reconstruction of the church might have occurred a generation or two later. In this second construction phase the original rectangular nave and the sacristy were demolished and replaced with a slightly wider presbytery, possibly with a polygonal closure. As regards the conversion of the building into a basilica, this is usually linked with events after 1328 when Štítnik received town privileges. Foundations of the north nave were investigated, as well as the pilasters separating the three nave arcades. These pilasters and pillars were built on the foundations of the original nave. The last major building work connected with the latest research was the construction of the triumphal arch and the rebuilding of the chancel, giving the church its present form. These changes took place, according to architects and historians, in the early 15 th century, which was confirmed by archaeological research. However, in contrast to the building and historical research, the authors of this paper believe that the mighty western tower comes from the final building phase of the church, or from the period of its conversion into a basilica.

The article is part of project no. 1/0727/17 of the VEGA scientific agency.

Mgr. Peter Tajkov, PhD., Fakulta umení Technickej univerzity v Košiciach, Letná 9, SK 04200 Košice, Slovenská republika,tajkov@yahoo.co.uk 
